\title{
Phagocytosis and ingestion of influenza virus by human polymorphonuclear leucocytes in vitro: electronmicroscopy studies
}

\author{
K. YAMAMOTO, K. SUZUKI*, K. SUZUKI† and S. MIZUNO†
}

Departments of Virology and Rickettsiology, "Technology and HAntibiotics, National Institute of Health, 2-1035 Kami-Osaki, Shinagawa-ku, Tokyo 141, Japan

\begin{abstract}
Summary. Interaction of human polymorphonuclear leucocytes (PMNL) and influenza virus (IFV) was studied in vitro. At $0^{\circ} \mathrm{C}$, the viral particles were bound extensively to the surface of the PMNL membrane with a ratio of about 1000 virus particles to a single PMNL. The binding was sensitive to neuraminidase, suggesting attachment through sialo-compound receptors. At $37^{\circ} \mathrm{C}$, the virus particles disappeared rapidly from the cell surface, about half of them being eluted and the remainder being endocytosed into the cytoplasmic vesicles. Immuno-gold electronmicroscopy suggests that the virus particles are ingested into phagosomal vesicles and lysed.
\end{abstract}

\section{Introduction}

Polymorphonuclear leucocytes (PMNL) provide the primary host defence against bacterial infection, by means of phagocytosis, lysosomal enzymes and the oxygen-dependent bactericidal system (Weissmann et al., 1971, 1973; Amano et al., 1975; Babior, 1978; Allen et al., 1981). Their role in virus infection, however, is not well established, although there have been several studies in vitro and in vivo. In the case of influenza virus (IFV), in-vitro studies have demonstrated PMNL damage, with suppression of chemotactic and phagocytic activities (Schlesinger et al., 1976; Ruutu et al., 1977; Kiyotani et al., 1985; Abramson et al., 1986; Moore and Mills, 1987). Indeed, IFV infection is sometimes followed by secondary bacterial infection, attributed to suppression of PMNL functions (Young et al., 1972; Fischer and Walker, 1979). On the other hand, there is evidence, from in-vivo studies, for an early protective role for these cells against IFV infection (Fujisawa et al., 1987; Tsuru et al., 1987), and activation of the oxygen-dependent microbicidal system, in the presence of IFV, is a possible mechanism for inactivation of the virus (Sweet and Smith, 1980; Mills et al., 1981).

In an attempt to elucidate more precisely the role of PMNL in virus infection, we have studied the interaction of human PMNL and IFV by electronmicroscopy.

Received 29 July 1988; accepted 15 Aug. 1988.

\section{Materials and methods}

Virus

Influenza virus, strain $\mathrm{A} / \mathrm{PR} / 8 / 34$ ( $\mathrm{H} 0 \mathrm{~N} 1$ ), was purified from the infected chorioallantoic fluid of embryonated hens' eggs by differential and sucrose-gradient centrifugation.

\section{Determination of plaque-forming units ( $p f u$ ) of virus}

This was done in the canine kidney cell line (MDCK), by the method of Tobita et al. (1975).

\section{Polymorphonuclear leucocytes}

These were prepared as described previously (Suzuki et al., 1983). Briefly, a suspension of PMNL and red blood cells was obtained from heparinised $(20 \mathrm{IU} / \mathrm{ml})$ peripheral blood of healthy adult volunteers by the method of Böyum (1968), with Lymphoprep (Nyegaard Co., Norway). The red blood cells were sedimented with dextran solution $1.5 \% \mathrm{w} / \mathrm{v}$ (mol. wt c. 200000 ; Nakarai Chemicals Ltd, Japan) and removed with lysis buffer. The PMNL were then washed twice with Dulbecco's phosphate-buffered saline without calcium and magnesium (PBS), by centrifugation at $350 \mathrm{~g}$ for $10 \mathrm{~min}$ at $20^{\circ} \mathrm{C}$, and suspended in Hanks's balanced salt solution (HBSS).

\section{Preparation of PMNL-IFV complexes}

For the electronmicroscopy studies, purified IFV60000 haemagglutinating (HA) units, equivalent to $c$. $10^{11} \mathrm{pfu}$-were mixed with $4 \times 10^{7} \mathrm{PMNL}$ in $40 \mathrm{ml}$ of 
HBSS at $0^{\circ} \mathrm{C}$. After $45 \mathrm{~min}$ at $0^{\circ} \mathrm{C}$, non-adsorbed virus was removed by centrifugation at $350 \mathrm{~g}$ for $5 \mathrm{~min}$ at $4^{\circ} \mathrm{C}$. The pellets of PMNL-IFV complexes were washed with cold PBS once and resuspended in one-twentieth of the original volume $(2.0 \mathrm{ml})$ of cold HBSS. The suspension was then placed, in $0 \cdot 5-\mathrm{ml}$ amounts, into Eppendorf microtubes and incubated at $37^{\circ} \mathrm{C}$. For virus-release experiment, a reduced virus (10 $000 \mathrm{HA})$ and PMNL $\left(4 \times 10^{7}\right)$ were mixed to increase the sensitivity of titration of the virus, and the complexes were resuspended in oneeighth of the original volume $(5 \mathrm{ml})$ of HBSS.

\section{Assay of virus liberated from the PMNL surface}

(1) Duplicate sets of virus-PMNL complexes were prepared and to one set bacterial neuraminidase (Boehringer Mannheim, Germany) was added to a concentration of $100 \mu \mathrm{g} / \mathrm{ml}$. At the end of each period of subsequent incubation, the suspensions were centrifuged at $1800 \mathrm{~g}$ for 5 min at $4^{\circ} \mathrm{C}$ and the supernates were titrated for virus HA activity, with chicken erythrocytes, in a cold room.

(2) The total amount of virus within the complexes, before incubation, was determined by solubilising the complexes with Triton X-100 $1 \%$ and then estimating viral neuraminidase activity. This was done by mixing equal volumes of the solubilised suspension and the neuraminidase substrate, fetuin (Gibco Laboratories, USA), $1.0 \%$ in $0.2 \mathrm{M}$ phosphate buffer ( $\mathrm{pH} 5.9$ ), and incubating for $30 \mathrm{~min}$ at $37^{\circ} \mathrm{C}$; released sialic acid was determined by the method of Aminoff (1961).

\section{Preparation for electronmicroscopy}

Samples of the PMNL-IFV complex suspensions were pre-fixed with a mixture of glutaraldehyde $2.5 \%$ and paraformaldehyde $2.0 \%$ in HBSS. After washing with PBS, by centrifugation at $8000 \mathrm{~g}$ for $2 \mathrm{~min}$ at $4^{\circ} \mathrm{C}$, they were post-fixed with $\mathrm{OsO}_{4} 1 \%$ in HBSS. Part of each sample was dehydrated and embedded in epoxy resin; ultrathin sections were cut, stained with uranylacetate $4 \%$ and examined with a Hitachi H-500 transmission electronmicroscope (TEM) at $75 \mathrm{kV}$. The rest of the sample was dehydrated, dried by the critical point method, coated with platinum-palladium by an ion-cater, and examined with a Hitachi S-700 scanning electronmicroscope (SEM).

\section{Immuno-gold electronmicroscopy}

PMNL-IFV complexes were incubated at $37^{\circ} \mathrm{C}$ for 30 min and then fixed with glutaraldehyde $2.5 \%$-paraformaldehyde $2.0 \%$, dehydrated, and embedded in Lowicryl $\mathrm{K} 4 \mathrm{M}$ resin with UV-irradiation. Thin sections were cut, and were treated with $5 \mathrm{HI}$ (haemagglutination inhibition) units of rabbit anti-PR8 IgG-purified through protein A-Sepharose (Pharmacia, Sweden)-followed by anti-rabbit IgG conjugated to 10 -nm-diameter colloidal gold (EY Laboratories Inc., USA) by the method of Roth (1982).

\section{Results}

\section{Binding of IFV to PMNL}

Serial 10-fold dilutions of a suspension of IFV, from $1.8 \times 10^{7}$ to $1.8 \times 10^{2} \mathrm{pfu}$, were added to an equal volume of a suspension of PMNL $\left(2 \times 10^{6}\right.$ cells $/ \mathrm{ml}$ ) at $0^{\circ} \mathrm{C}$. The mixtures were centrifuged at $1800 \mathrm{~g}$ for $5 \mathrm{~min}$ at $4^{\circ} \mathrm{C}$ and the amount of unadsorbed virus in each supernate was determined (table I). Adsorption of more than $80 \%$ of added virus was attained with virus concentrations of $9.0 \times 10^{4}$ pfu and lower, but the adsorption level decreased to $30-50 \%$ with higher virus concentrations.

\section{SEM examination of PMNL-IFV complexes}

An excess amount of IFV was added to human PMNL at $0^{\circ} \mathrm{C}$ and the mixture was allowed to stand at $0^{\circ} \mathrm{C}$ for $45 \mathrm{~min}$. The PMNL were then recovered by centrifugation, fixed and examined by SEM (fig. 1). Fig. 1a shows extensive attachment of virus particles to the surface of the cell membrane. About 1000 particles were found to bind to a single PMNL (fig. 2). When the PMNL-IFV complexes were incubated at $37^{\circ} \mathrm{C}$, the countable virus particles on the cell surface rapidly decreased (figs. 1b-d); after $10 \mathrm{~min}$, the number of adsorbed virus particles decreased by about $80 \%$, and by greater than $99 \%$ after $30 \mathrm{~min}$ (fig. 2).

\section{Nature of the association between PMNL and IFV}

Because IFV adsorbed to the cell surface of red blood cells and respiratory epithelial cells detaches when incubated at $37^{\circ} \mathrm{C}$ (Hirst, 1942, 1943), we examined whether this was also so with PMNL. Mixtures of virus and cells were incubated (see

Table I. Adsorption of IFV to PMNL at various virus doses

\begin{tabular}{lcc}
\hline Amount of virus (pfu/0.1 ml) & \\
\cline { 1 - 1 } added* & unadsorbed & $\begin{array}{c}\text { Adsorption } \\
\text { ratio }(\%)\end{array}$ \\
\hline $9.0 \times 10^{6}$ & $6.0 \times 10^{6}$ & 33.3 \\
$9.0 \times 10^{5}$ & $4.2 \times 10^{5}$ & 53.3 \\
$9.0 \times 10^{4}$ & $1.9 \times 10^{4}$ & 80.0 \\
$9.0 \times 10^{3}$ & $1.3 \times 10^{3}$ & 85.6 \\
$9.0 \times 10^{2}$ & $0.6 \times 10^{2}$ & 93.3 \\
$9.0 \times 10^{1}$ & $1.1 \times 10^{1}$ & 87.8 \\
\hline
\end{tabular}

* Each dilution of virus was mixed with an equal volume of PMNL suṣpension $\left(2 \times 10^{6}\right.$ cells $\left./ \mathrm{ml}\right)$. 

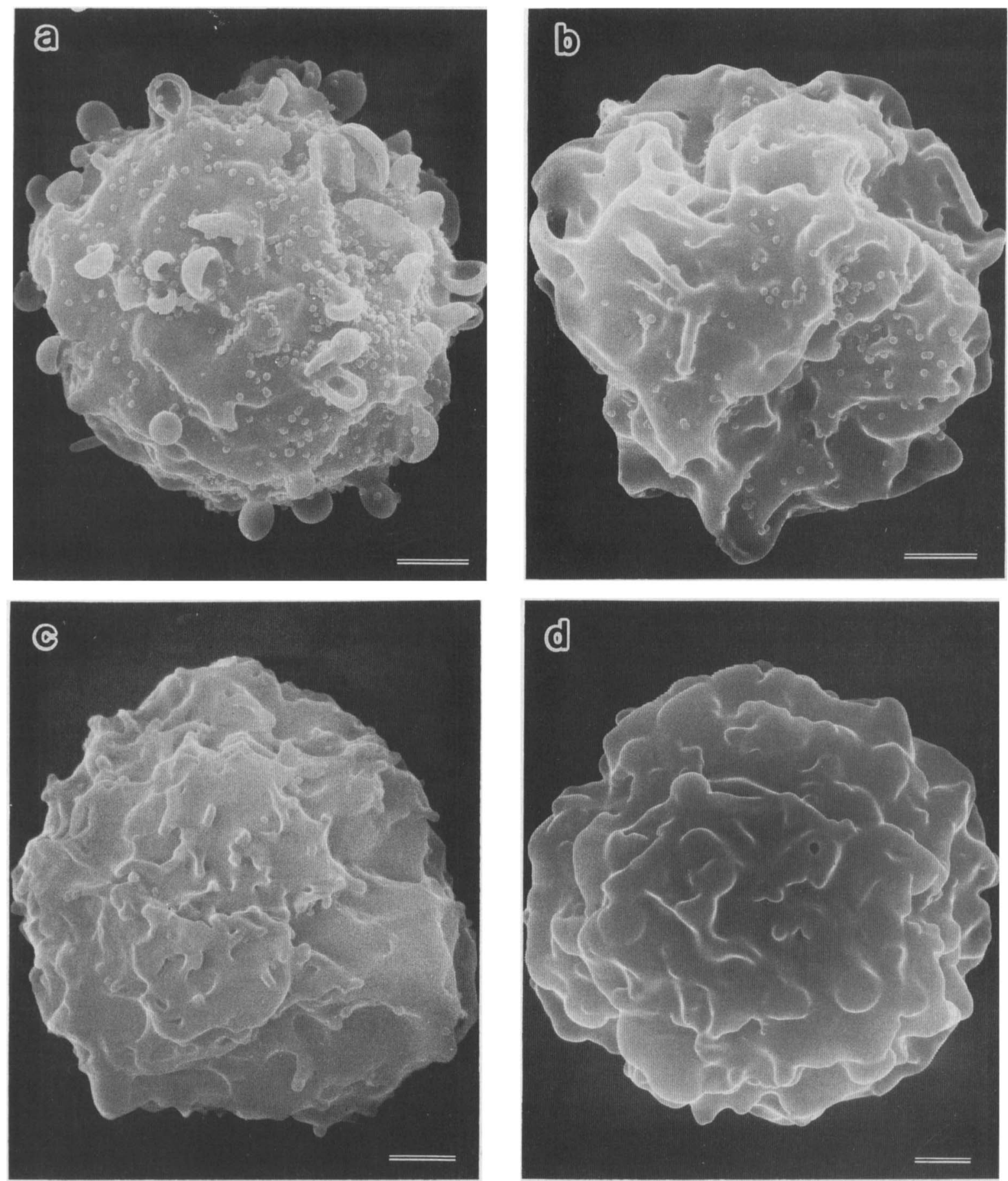

Fig. 1. Scanning electronmicrograph (SEM) of PMNL mixed with IFV, showing loss of adsorbed virus particles after incubation at $37^{\circ} \mathrm{C}$ for (a) $0 \mathrm{~min}$, (b) $2 \mathrm{~min}$, (c) $10 \mathrm{~min}$ and (d) $30 \mathrm{~min}$. Scale $=1 \mu \mathrm{m}$. 


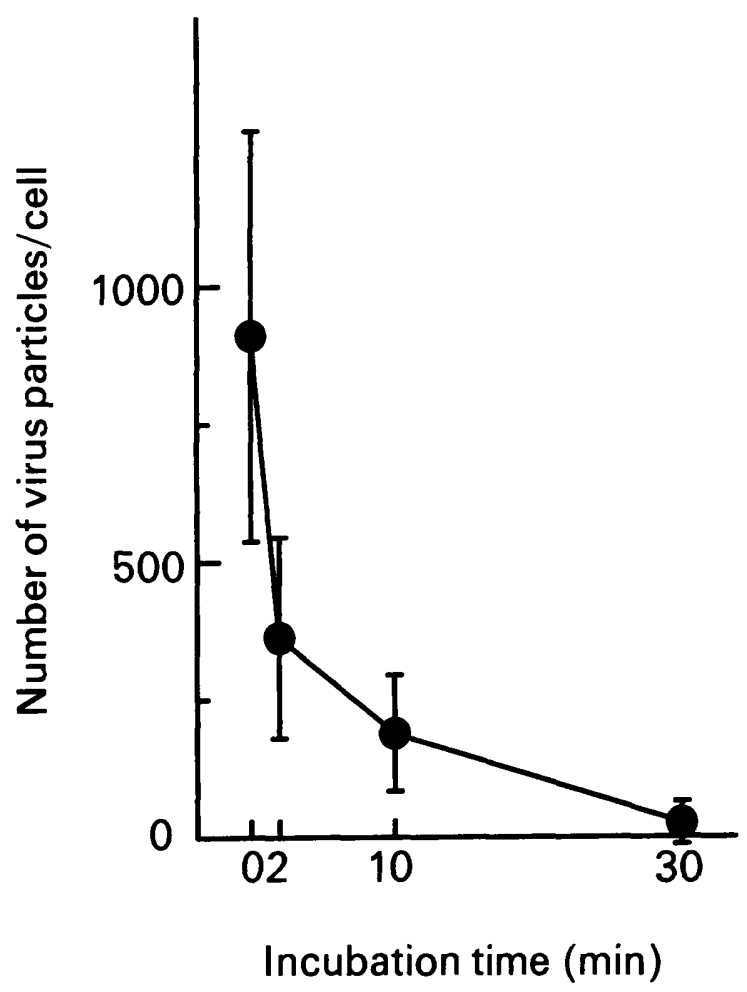

Fig. 2. Number of virus particles bound per PMNL cell surface after incubation at $37^{\circ} \mathrm{C}$. Counts are the average from 15 cells examined by SEM. Particles were counted on the upper cell surface and the number was doubled to give an estimate for the whole cell surface. Bars represent SD.

Materials and methods) and, after centrifugation, the supernates were titrated for virus HA. The HA titre in the supernate increased with the time of incubation, to reach a maximal level after $20 \mathrm{~min}$ (fig. 3). Bacterial neuraminidase added to the viruscell mixture did not increase the amount of HA released during the incubation period (fig. 3).

The total amount of virus present within the

Table II. Release of IFV from PMNL-virus complexes after incubation at $37^{\circ} \mathrm{C}$

\begin{tabular}{|c|c|c|c|}
\hline $\begin{array}{l}\text { Period of } \\
\text { incubation } \\
\text { (min) }\end{array}$ & $\begin{array}{c}\text { Sample } \\
\text { tested for } \\
\text { neuraminidase } \\
\text { activity }\end{array}$ & $\begin{array}{c}\text { Neuraminidase } \\
\text { activity } \\
\text { (adsorption } \\
\text { at } 549 \mathrm{~nm} \text { ) }\end{array}$ & $\begin{array}{c}\text { Virus } \\
\text { release } \\
(\%)\end{array}$ \\
\hline 0 & supernate & 0.045 & $25 \cdot 0$ \\
\hline 5 & supernate & 0.060 & $33 \cdot 3$ \\
\hline 10 & supernate & 0.080 & $44 \cdot 4$ \\
\hline \multirow{3}{*}{$\stackrel{30}{-}$} & supernate & 0.090 & $50 \cdot 0$ \\
\hline & solubilised & & \\
\hline & complex* & 0.180 & $100 \cdot 0$ \\
\hline
\end{tabular}

* Without incubation.

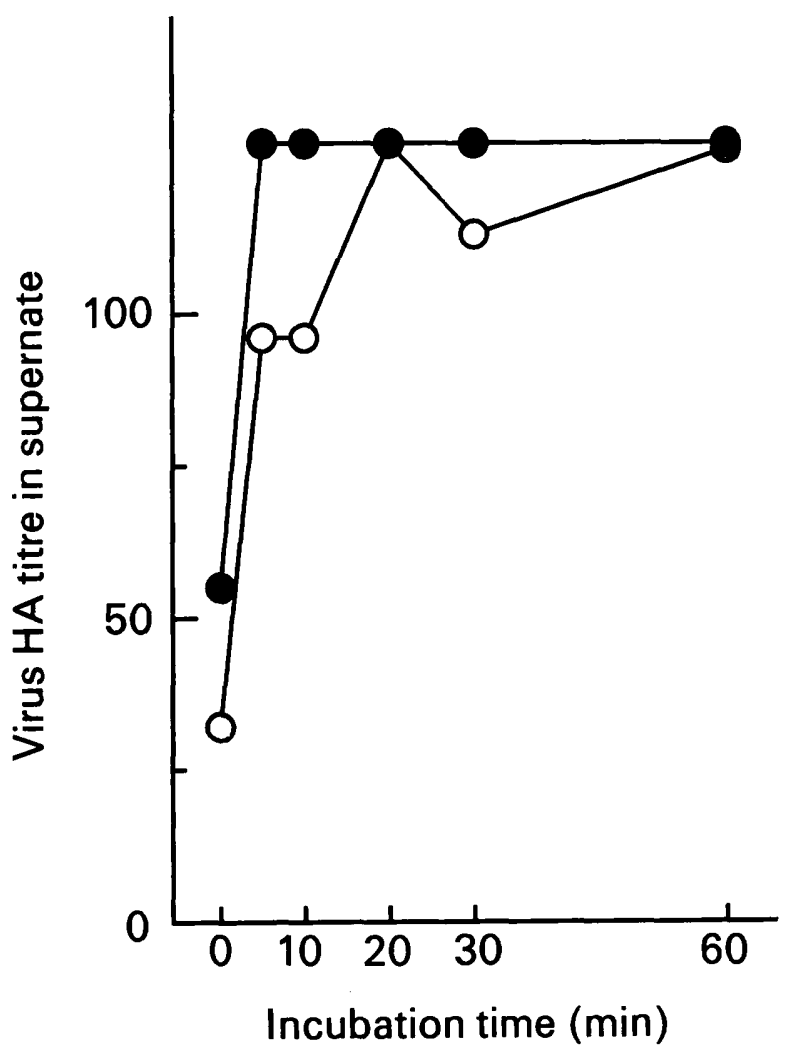

Fig. 3. Release of IFV from PMNL surface after incubation at $37^{\circ} \mathrm{C}$, with (-O) or without $(\mathrm{O}-\mathrm{O})$ added bacterial neuraminidase.

PMNL-virus complexes was determined by solubilisation of the complexes with Triton X-100 and assay of viral neuraminidase activity; the HA technique does not measure cell-bound virus activity (table II). When non-solubilised virus-cell mixtures were incubated at $37^{\circ} \mathrm{C}$ and the supernates tested for neuraminidase activity, only about $44 \%$ of the total available neuraminidase activity was released into the supernate after $10 \mathrm{~min}$, with only a slight further release, to $50 \%$, after $30 \mathrm{~min}$. This contrasted with less than $1 \%$ of virus particles visible by SEM on the PMNL after incubation for 30 min (figs. 1 and 2).

\section{Phagocytosis of virus by PMNL}

To investigate the possible internalisation of IFV within the cells, we examined the PMNL-IFV complexes by TEM. Fig. 4a shows that, before incubation, virus particles were observed only on the surface of PMNL. When the complexes were incubated at $37^{\circ} \mathrm{C}$ for $2 \mathrm{~min}$, endocytosed virus particles were clearly demonstrable within cytoplasmic vesicles, with many virus particles remain- 

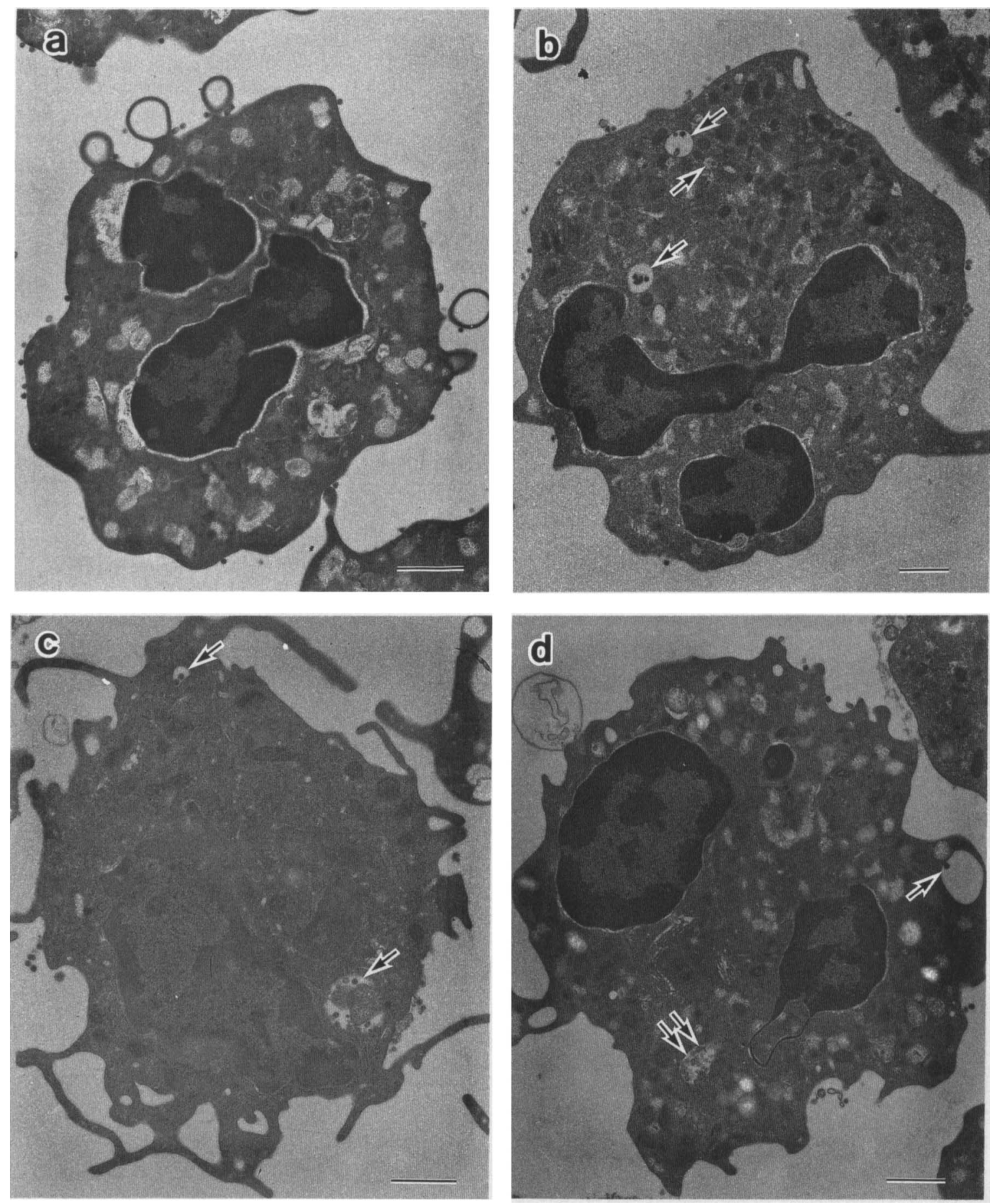

Fig. 4. Transmission electronmicrograph (TEM) of PMNL mixed with IFV, showing the presence of intact (single arrows) and deformed (double arrow) particles within cytoplasmic vacuoles, after incubation at $37^{\circ} \mathrm{C}$ for (a) $0 \mathrm{~min}$, (b) $2 \mathrm{~min}$, (c) $10 \mathrm{~min}$ and (d) $30 \mathrm{~min}$. Scale $=1 \mu \mathrm{m}$. 
ing at the cell surface, which agreed with the results of SEM observation. On further incubation for 10 $30 \mathrm{~min}$, small phagosomes with a few virus particles (figs. 4b, c) and larger phagosomes containing many virus particles (fig. 4c) or a single particle (single arrow in fig. 4d) were seen. As indicated by the double arrow in fig. $4 \mathrm{~d}$, fuzzy particles, as if being digested or degraded in the phagosomal vesicle, were observed together with intact virus particles.

\section{Detection of viral antigen within the phagosome vesicles}

When the ultrathin sections of PMNL-IFV complexes, without incubation, were treated with anti-IFV IgG and then with gold-labelled anti-IgG, colloidal gold grains were observed associated with virus particles on the PMNL surface membrane but not in the cytoplasm (fig. 5a), indicating viral antigen-specific binding of the colloidal gold. On the other hand, when the complexes were incubated at $37^{\circ} \mathrm{C}$ for $10 \mathrm{~min}$, many gold grains were seen associated with both intact and deformed virus particles within the phagosomal vesicles of the cytoplasm (fig. 5b).

\section{Discussion}

As expected from previous reports (Abramson et

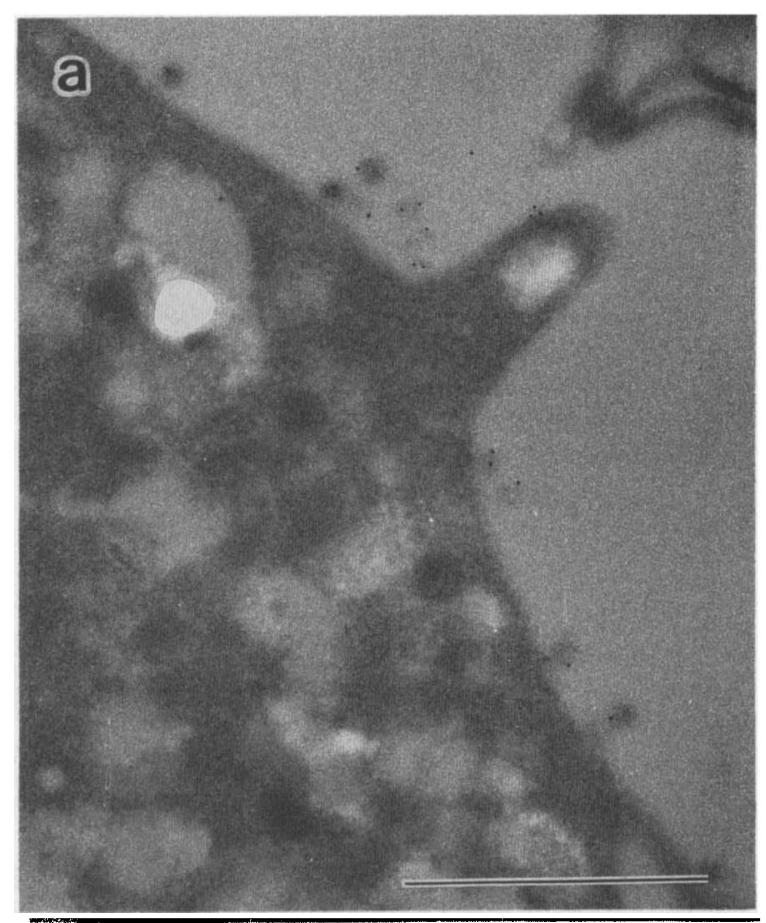

al., 1986; Moore and Mills, 1987), IFV bound extensively to human PMNL in vitro. The binding of virus was more than $80-90 \%$ efficient, but failed to reach $100 \%$ even with the highest dilution of virus. This does not necessarily mean weak binding activity, as similar incomplete adsorption was also observed with MDCK cells, which readily support the replication of IFV (data not shown). Effective adsorption was confirmed by SEM, which demonstrated approximately 1000 virus particles on the surface of each PMNL (fig. 2).

SEM observation also showed that after incubation at $37^{\circ} \mathrm{C}$ the virus particles on the cell surface rapidly disappeared. This could be due either to phagocytosis of the virus particles by the PMNL or to their release from the cell surface by their own specific receptor-destroying enzyme. Virus release undoubtedly occurs, and the close correspondence between the amounts of virus HA released on incubation in the presence and absence of bacterialderived neuraminidase strongly suggests that the virus binds to the PMNL surface through a sialocompound receptor specific for IFV. However, no more than half the total virus amount associated with cells, as estimated after solubilisation of the virus-cell complexes, could be liberated. This appeared to contradict the SEM findings, namely that fewer than $1 \%$ of the virus remained on the cell

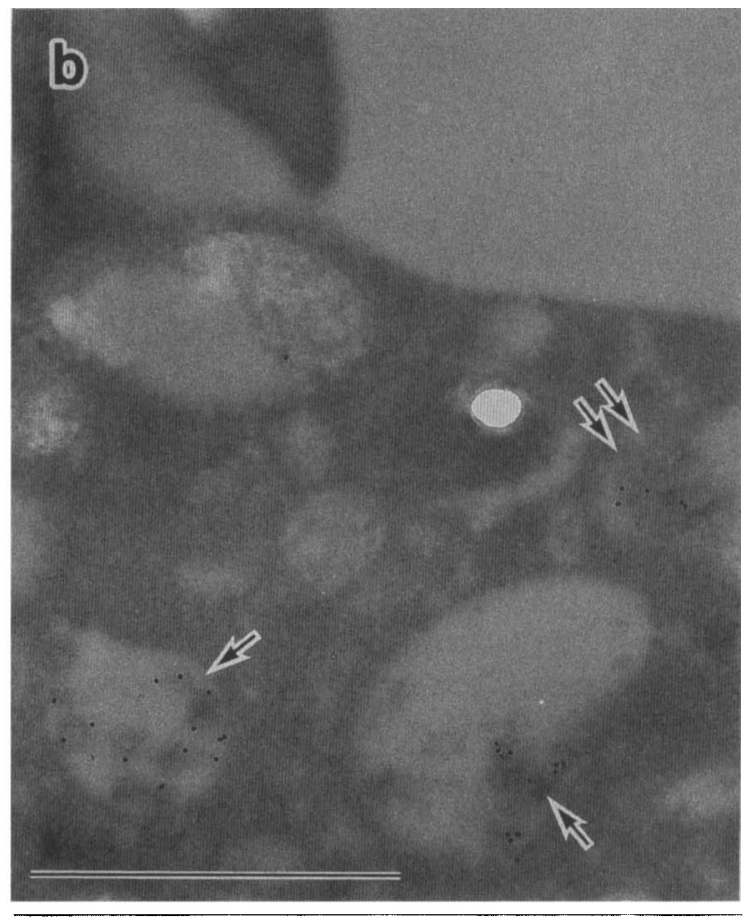

Fig. 5. Immuno-gold electronmicrograph of PMNL mixed with IFV, after incubation at $37^{\circ} \mathrm{C}$ for (a) 0 min and (b) $10 \mathrm{~min}$, showing intact (single arrows) and fuzzy (double arrow) virus particles. Scale $=1 \mu \mathrm{m}$. 
surface, suggesting that IFV was taken into the cells. Indeed, this was confirmed by the TEM results. The loss of IFV particles from the PMNL surface, on incubation, is, therefore, due to the mutually competitive activities of phagocytosis and receptor-destroying release.

The TEM experiments showed that the phagocytic activity of the PMNL was temperaturedependent, no virus particles being detected within the phagosomes after standing at $0^{\circ} \mathrm{C}$. This agrees with the electronmicroscopy observations of Abramson et al. (1986). At $37^{\circ} \mathrm{C}$, virus particles rapidly appeared in the phagosomes within the first 2 min of incubation and phagocytosis progressed thereafter. The virus particles in the phagosomes looked intact, with rigid conformation, during the first 2-10 min of incubation, but became fuzzy in appearance after $30 \mathrm{~min}$. This suggests that the phagocytosed viruses are subsequently digested by lysosomal enzymes.

In host defence, macrophages are known to respond to virus infection, but, as they frequently support the growth of viruses, they are not always defensive against invading viruses (Mogensen, 1979; Inada and Mims, 1984; Nagai et al., 1985;

\section{REFERENCES}

Abramson J S et al. 1986 Suppression of endocytosis in neutrophils by influenza A virus in vitro. Journal of Infectious Diseases 154: 456-463.

Allen R C, Mills E L, McNitt T R, Quie P G 1981 Role of myeloperoxidase and bacterial metabolism in chemiluminescence of granulocytes from patients with chronic granulomatous disease. Journal of Infectious Diseases 144: 344-348.

Amano D, Kagosaki Y, Usui T, Yamamoto S, Hayaishi O 1975 Inhibitory effects of superoxide dismutases and various other proteins on the nitroblue tetrazolium reduction by phagocytizing guinea pig polymorphonuclear leukocytes. Biochemical and Biophysical Research Communication 66: 272-279.

Aminoff D 1961 Methods for the quantitative estimation of Nacetylneuraminic acid and their application to hydrolysates of sialomucoids. Biochemical Journal 81 : 384-392.

Babior B M 1978 Oxygen-dependent microbial killing by phagocytes. New England Journal of Medicine 298: 659-668.

Böyum A 1968 Isolation of mononuclear cells and granulocytes from human blood. Scandinavian Journal of Clinical and Laboratory Investigation 21 Suppl 97 : 77-89.

Cardosa M J, Gordon S, Hirsh S, Springer T A, Porterfield J S 1986 Interaction of West Nile virus with primary murine macrophages: Role of cell activation and receptors for antibody and complement. Journal of Virology 57: 952-959.

Domke-Opitz I, Straub P, Kirchner H 1986 Effect of interferon on replication of herpes simplex virus types 1 and 2 in human macrophages. Journal of Virology 60 : 37-42.

Fischer J J, Walker D H 1979 Invasive pulmonary aspergillosis associated with influenza. Journal of American Medical Association 241 : 1493-1494.
Rowson and Mahy, 1985; Rossiter and Wardley, 1985; Cardosa et al., 1986; Domke-Opitz et al., 1986; Koenig et al., 1986). On the other hand, studies on the role of PMNL in virus infection are very few. There are several reports that the biological functions of PMNL are suppressed in the presence of IFV (Schlesinger et al., 1976; Ruutu et al., 1977; Kiyotani et al., 1985; Abramson et al., 1986; Moore and Mills, 1987). More recently, a protective role has been suggested for PMNL in the early stages of IFV infection (Fujisawa et al., 1987; Tsuru et al., 1987). In these studies, however, the evidence for protection was indirect, based on the use of $\gamma$-irradiated or carageenan-treated mice. Our electronmicroscopy study has directly demonstrated, in vitro, that PMNL extensively adsorb and then phagocytose IFV, possibly into phagosomal vesicles. Moreover, we have unpublished data that PMNL are non-permissive for growth of IFV. Therefore, these present observations suggest a possible role for PMNL as a virus-killing factor in the early stages of virus infection. We are currently studying the inactivation of IFV by PMNL by biochemical approaches.

Fujisawa H, Tsuru S, Taniguchi M, Zinnaka Y, Nomoto K 1987 Protective mechanisms against pulmonary infection with influenza virus. 1. Relative contribution of polymorphonuclear leukocytes and of alveolar macrophages to protection during the early phase of intranasal infection. Journal of General Virology 68 : 425-432.

Hirst G K 1942 Adsorption of influenza hemagglutinins and virus by red blood cells. Journal of Experimental Medicine 76: 195-209.

Hirst G K 1943 Adsorption of influenza virus on cells of the respiratory tract. Journal of Experimental Medicine 78: 99109.

Inada T, Mims C A 1984 Mouse Ia antigens are receptors for lactate dehydrogenase virus. Nature 309: 59-61.

Kiyotani K, Takei N, Matsuno Y 1985 Depression of luminolenhanced chemiluminescence of guinea pig polymorphonuclear leukocytes by influenza virus with special reference to neuraminidase. Hiroshima Journal of Medical Sciences 34: $81-86$.

Koenig S et al. 1986 Detection of AIDS virus in macrophages in brain tissue from AIDS patients with encephalopathy. Science 233: 1089-1093.

Mills E L, Debets-Ossenkopp Y, Verbrugh H A, Verhoef J 1981 Initiation of the respiratory burst of human neutrophils by influenza virus. Infection and Immunity 32: 1200-1205.

Mogensen S C 1979 Role of macrophages in natural resistance to virus infections. Microbiological Reviews 43: 1-26.

Moore D L, Mills E L 1987 Characterization of the chemotactic defect in polymorphonuclear leukocytes exposed to influenza virus in vitro. Blood $70: 351-355$.

Nagai T et al. 1985 Isolation of haemorrhagic fever with renal syndrome virus from leukocytes of rats and virus replication in cultures of rat and human macrophages. Journal of General Virology 66: 1271-1278. 
Rossiter P B, Wardley R C 1985 The differential growth of virulent and avirulent strains of rinderpest virus in bovine lymphocytes and macrophages. Journal of General Virology 66: 969-975.

Roth J 1982 The protein A-gold (pAg) qualitative and quantitative approach for antigen localization on thin sections. In: Bullock G R, Petrusz P (eds) Techniques in immunocytochemistry, vol 1 . Academic Press, London and New York, pp 107-133.

Rowson K E K, Mahy B W J 1985 Lactate dehydrogenaseelevating virus. Journal of General Virology 66 : 2297-2312.

Ruutu P, Vaheri A, Kosunen T U 1977 Depression of human neutrophil motility by influenza virus in vitro. Scandinavian Journal of Immunology 6: 897-906.

Schlesinger J J, Ernst C, Weinstein L 1976 Inhibition of human neutrophil chemotaxis by influenza virus. Lancet 1 : 650 651.

Suzuki K, Ota H, Sasagawa S, Sakatani T, Fujikura T 1983 Assay method for myeloperoxidase in human polymorphonuclear leukocytes. Analytical Biochemistry 132: 345-352.

Sweet C, Smith H 1980 Pathogenicity of influenza virus. Microbiological Reviews 44: 303-330.
Tobita K, Sugiura A, Enomoto C, Furuyama M 1975 Plaque assay and primary isolation of influenza $A$ viruses in an established line of canine kidney cells (MDCK) in the presence of trypsin. Medical Microbiology and Immunology 162: 9-14.

Tsuru S, Fujisawa H, Taniguchi M, Zinnaka Y, Nomoto K 1987 Mechanism of protection during the early phase of a generalized viral infection. II. Contribution of polymorphonuclear leukocytes to protection against intravenous infection with influenza virus. Journal of General Virology 68: 419-424.

Weissmann G, Zurier R B, Spieler P J, Goldstein I M 1971 Mechanisms of lysosomal enzyme release from leukocytes exposed to immune complexes and other particles. Journal of Experimental Medicine 134 Suppl. 149-165.

Weissmann G, Zurier R B, Hoffstein S 1973 Leukocytes as secretory organs of inflammation. Agents Actions 3: 370379.

Young L S, Laforce M, Head J J, Feeley B S, Bennett J V 1972 A simultaneous outbreak of meningococcal and influenza infections. New England Journal of Medicine 287 : 5-9. 